\title{
Dual Mode-Multiple Output SEPIC Converter Integrated with Passive Ripple Cancelling Circuit for Standalone PV Energy Harvesting System
}

\author{
Sharmin Sobhan1*, Md. Ashraful Hoque², Golam Sarowar', Tanvir Ahmad1, Abdul Mannan Farhan ${ }^{3}$ \\ ${ }^{1}$ Department of Electrical \& Electronic Engineering, Ahsanullah University of Science \& Technology, Dhaka, Bangladesh \\ ${ }^{2}$ Department of Electrical \& Electronic Engineering, Islamic University of Technology, Dhaka, Bangladesh \\ ${ }^{3}$ Martin Luther University of Halle-Wittenberg, Halle, Germany \\ Email: *sharmin_sobhan@yahoo.com
}

How to cite this paper: Sobhan, S., Hoque, M.A., Sarowar, G., Ahmad, T. and Farhan, A.M. (2016) Dual Mode-Multiple Output SEPIC Converter Integrated with Passive Ripple Cancelling Circuit for Standalone PV Energy Harvesting System. Journal of Power and Energy Engineering, 4, 1-18. http://dx.doi.org/10.4236/jpee.2016.411001

Received: October 13, 2016

Accepted: November 21, 2016

Published: November 24, 2016

Copyright $\odot 2016$ by authors and Scientific Research Publishing Inc. This work is licensed under the Creative Commons Attribution International License (CC BY 4.0).

http://creativecommons.org/licenses/by/4.0/

\section{Abstract}

This document addresses an exhaustive standalone Photovoltaic (PV) energy harvesting system considering two crucial issues: system efficiency and cost effectiveness. It contributes a compact resolution with a combined feature of Dual ModeMultiple Output (DMMO) associated with input ripple reduction technique. Control strategy incorporates with aspect of Maximum Power Point Tracking (MPPT) and output voltage levels regulation. A theoretical analysis is conducted to evaluate the effect of ripple current on PV power. Proposed dual mode converter achieves efficiency of $98.36 \%$ and $97.76 \%$ respectively for mode- 1 and mode- 2 operation. However, simulation is performed applying MATLAB/SIMULINK tools to analyze the feasibility of the recommended system.

\section{Keywords}

Photovoltaic Cell, Current Ripple Reduction, Dual Mode Converter, Multiple Outputs, Efficiency

\section{Introduction}

Along with the decreasing storage of the fossil fuels and rising environmental concerns, the sustainable energy sources, such as the photovoltaic (PV), fuel cells, and wind energy are taken as the promising appellants for future energy supply. Furthermore, backup storage elements are required to consume the irregular energy fluctuation generated by the sustainable energy sources [1] [2] [3]. Stand-alone systems are independent of utility grids; require storage elements to accommodate the intermittent generation of 
solar energy [4] [5] [6] [7]. However, the output voltages of each PV panel and back-up battery cell are quite low; hence arise the need of high step-up and high-efficiency converters to upgrade the low voltage [8] [9] [10].

High frequency applications spontaneously develop current ripples in switching power converters, which may cause momentous impact on the output power [11] [12]. This ripple current influences filtering problems, control issues, output voltage noise, and other hurdles. Ripple reduction techniques contribute an approach for improved power converter performance. A simple and low cost Passive Ripple Cancelling Circuit (PRCC) [13] has been invented. Special features of the proposed PRCC include low cost, simple, modular structure, and independent of the duty ratio control of the main power circuit.

Multilevel converter facilitates the use of renewable energy sources and attains high power ratings, as well as accommodates multiple users. However, multiple-output dc$\mathrm{dc}$ converter is a potential solution for applications requiring multiple supplies where the output voltages and power for each supply are largely different according to user's requirement and distance [14] [15] [16].

High-Voltage DC (HVDC) systems [17] are used exclusively for long distance, which grant higher efficiency and potentially reduce the cost. However, for short distance, Low Voltage Direct Current (LVDC) is a promising solution [18], which facilitates large power shifting capacity with low voltage and improvements to reliability and power quality.

This paper investigates the effect of ripple current on PV output power for single diode model with series and shunt resistance as well as proposes a complete standalone $\mathrm{PV}$ energy harvesting system with an effective ripple reduction technique. Comprehensive system is accompanied by Dual Mode-Multiple Output (DMMO) properties and control strategy to realize flexible power flow and high power capability.

\section{Proposed System}

Figure 1 exhibits the overview of the proposed system.

- A Photovoltaic module with standalone property is connected with a DC-DC converter. Converter is incorporate with the ability to work as dual state SEPIC converter facilitate both high voltage and low voltage system.

- To reduce the input current ripple, ripple reduction technique is integrated into the converter.

- Multiple-output dc-dc converter is a potential solution for applications requiring multiple supplies. The proposed system will be capable of delivering different output voltage levels from single dc-dc converter at the load side.

- At the situation when single voltage level is required among various levels, multiplexing scheme can be embedded into load side to fulfill user's requirements (Figure 1).

\subsection{Impact of Current Ripple on Generated Power of Single Diode PV Module with Series and Shunt Resistances}

Single diode model is the simplest as it has a current source in parallel to a diode. This 


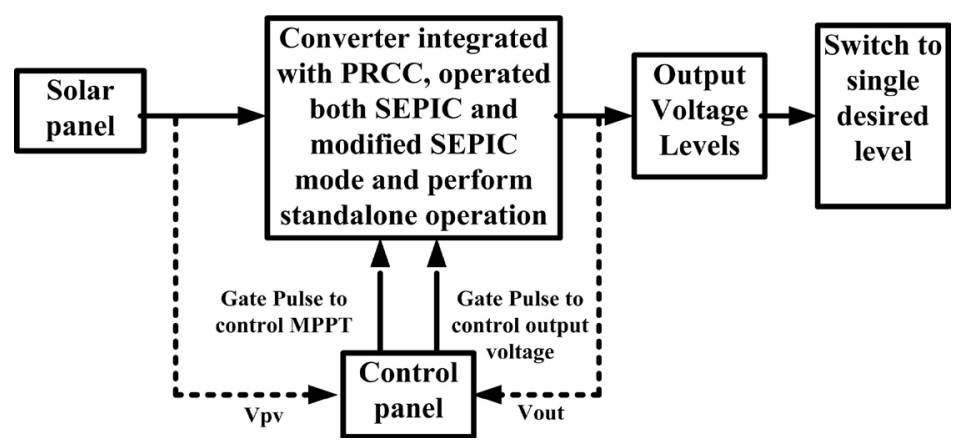

Figure 1. Block diagram of the proposed system.

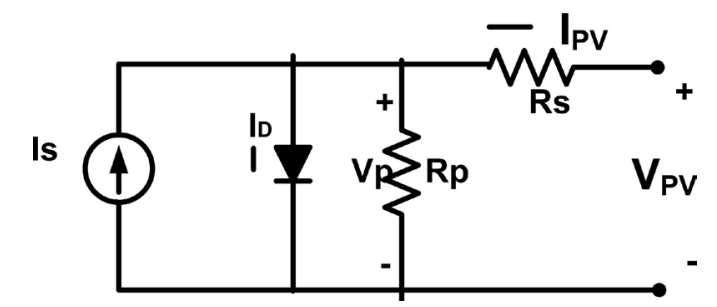

Figure 2. Mathematical model of PV module with series and shunt resistance [19] [20].

model is upgraded by the inclusion of one series resistance, $R_{s}$ [21] [22]. In spite of its simplicity; it exhibits acute deficiencies when suffered from temperature deviations. An accretion of the model which introduces a supplementary shunt resistance $R_{p}$ [23] [24] is shown in Figure 2.

I-V characteristics of PV module [25] [26] can be represented as:

$$
I_{P V}=I_{s}-I_{o}\left[\mathrm{e}^{\frac{V_{P V}+I_{P V} \cdot R_{s}}{\alpha}}-1\right]-\frac{V_{P}}{R_{P}}
$$

where, $\alpha=A \cdot V_{T}$

$$
V_{T}=\frac{K T}{q}
$$

Different Parameters:

- $I_{s}$ is the current generated by the incident light.

- $I_{o}$ is the reverse saturation current.

- $q$ is the electron charge $\left[1.60217646 \times 10^{-19} \mathrm{C}\right]$.

- $k$ is the Boltzmann constant $\left[1.3806503 \times 10^{-23} \mathrm{~J} / \mathrm{K}\right]$.

- $T[\mathrm{~K}]$ is the temperature of the $\mathrm{p}-\mathrm{n}$ junction.

- $A$ is ideality factor of diode.

- $V_{T}$ is the thermal voltage of the module.

- $R_{s}$ is the series resistance of the module.

- $R_{p}$ is the parallel resistance of the module.

From Equation (1), the output voltage of PV module can be derived as follows:

$$
V_{P V}=\alpha \cdot \ln \left[\frac{I_{s}+I_{o}-I_{P V}}{I_{o}}-\left(\frac{V_{P}}{I_{o} \cdot R_{P}}\right)\right]-I_{P V} \cdot R_{s}
$$


Multiplying Equation (2) by $I_{p \text { r }}$ the output power of PV module can be obtained,

$$
P_{P V}=I_{P V} \cdot \alpha \cdot \ln \left[\frac{I_{s}+I_{o}-I_{P V}}{I_{o}}-\left(\frac{V_{P}}{I_{o} \cdot R_{P}}\right)\right]-I_{P V}^{2} \cdot R_{s}
$$

From Equation (1) to Equation (3), it is observe that the $I_{p r}, V_{p r}$ and $P_{p v}$ are usually considered as pure DC values. However, in practical applications, the output voltage and current of PV module contain ripple components caused by the front-end converter of the system and this may cause significant impact on the output power. Hence appear the urgency to use a ripple reduction technique with the PV module.

Figure 3 shows PV output power perturbation caused by periodical ripple current. From Figure 3, periodically variation of $p_{p_{v}}$ due to periodical variation of $i_{p \text { r }}$, can easily be observed. As an illustration, consider a switching period from $t=0$ to $t=T_{s}$ for the case when PV module is operated near MPP assuming the irradiance is fixed as shown in Figure 3(b). When the active switch is turned on, $i_{p V}$ will increase from $I_{a}$ to $I_{b}$ for $t \in$ $\left[0, D T_{s}\right]$. At the same time, the corresponding $p_{p v}$ trajectory is varied from $P_{a}$ to $P_{b}$. It is seen that during this interval, the MPP is achieved only at one point [13].

Similarly, when the switch is turned off, $i_{p v}$ will decrease from $I_{b}$ to $I_{a}$ for $t \in\left[D T_{s}\right.$, $T_{s}$. The corresponding $p_{p V}$ is varied from $P_{b}$ to $P_{a}$. Again, the MPP is achieved only at one point. Obviously, from Figure $3(\mathrm{~b})$ it is clearly seen that the average power $P_{P V \text { avrg }}$ is less than the available maximum PV output power $P_{M}$.

To analyze the ripple-affected power loss of PV module, at first, the $i_{p V}$ can be defined as a periodically time-variant function as $i_{p v}(t)$.

- $I_{P V, r}(t)$ represents the current in the rising period.

- $I_{P V, t}(t)$ represents the current in the falling period.

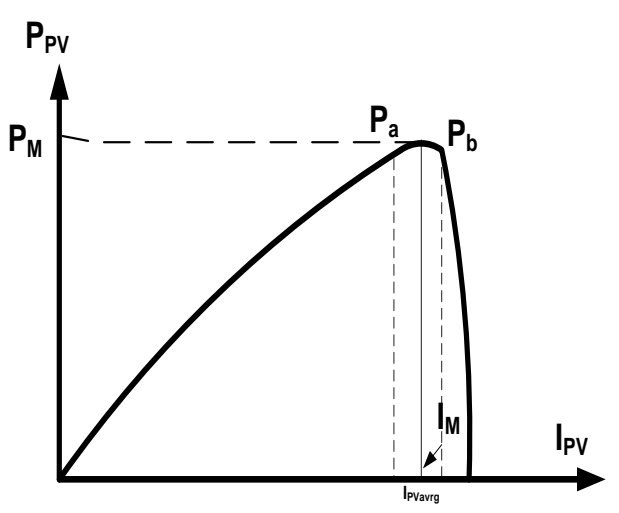

(a)
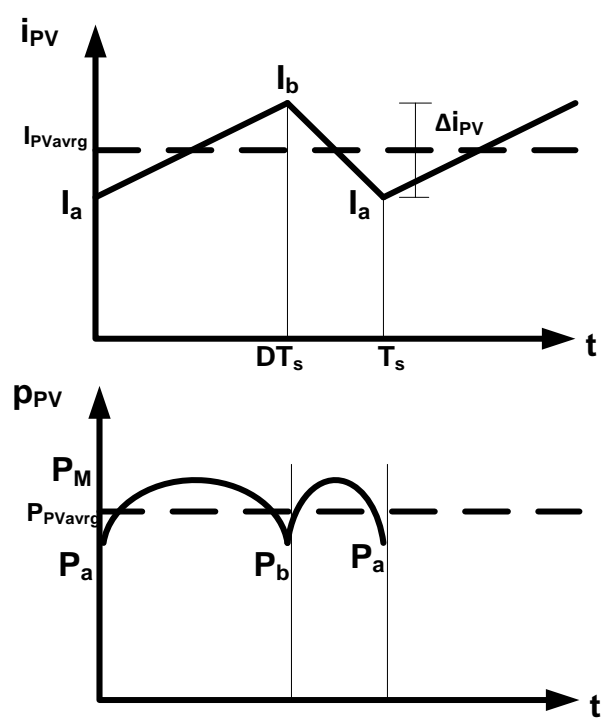

(b)

Figure 3. Illustrations of PV output power perturbation caused by ripple current. (a) P-I curve, (b) time-variant waveforms of $i_{P V}$ and $P_{P V}$ [13]. 
- $I_{P V, \text { avrg }}$ represents the average value of PV current.

- $\Delta i_{P V}$ is the ripple current.

- $D$ is the duty ratio.

- $T_{s}$ is the switching period.

For rise time,

$$
i_{P V, r}(t)= \begin{cases}\frac{t-n T_{s}}{D T_{s}} \cdot \Delta i_{P V}+I_{P V, \text { avrg }}-\frac{\Delta i_{P V}}{2}, & t \in\left[n T_{s},(n+D) T_{s}\right] \\ 0, & t \notin\left[n T_{s},(n+D) T_{s}\right]\end{cases}
$$

For fall time,

$$
i_{P V, r}(t)= \begin{cases}\frac{-\Delta i_{P V}}{(1-D) T_{s}} \cdot t+I_{P V, a v r g}+\Delta i_{P V} \frac{(1+D)}{2(1-D)}, & t \in\left[(n+D) T_{s},(n+1) T_{s}\right] \\ 0, & t \notin\left[(n+D) T_{s},(n+1) T_{s}\right]\end{cases}
$$

Periodically time-variant function of the PV output power can be described as:

$$
\begin{aligned}
p_{P V}= & p_{P V, r}(t) \cdot\left[u\left(t-n T_{s}\right)-u\left(t-(n+D) T_{s}\right)\right] \\
& +p_{P V, f}(t) \cdot\left[u\left(t-(n+D) T_{s}\right)-u\left(t-(n+1) T_{s}\right)\right]
\end{aligned}
$$

Then, substituting Equation (4) and Equation (5) into Equation (3), $P_{P V, r}(t)$ and $P_{P V, A}(t)$ can be derived as follows:

$$
\begin{aligned}
& p_{P V, r}(t)=-\left(\frac{t-n T_{S}}{D T_{s}} \cdot \Delta i_{P V}+I_{P V, a v r g}-\frac{\Delta i_{P V}}{2}\right)^{2} R_{s} \\
& +\left(\frac{t-n T_{S}}{D T_{s}} \cdot \Delta i_{P V}+I_{P V, \text { avrg }}-\frac{\Delta i_{P V}}{2}\right) \cdot \alpha \cdot \ln \beta \\
& \text { where, } \beta=\left[\frac{I_{s}+I_{o}-\left(\frac{t-n T_{S}}{D T_{s}} \cdot \Delta i_{P V}+I_{P V, \text { avrg }}-\frac{\Delta i_{P V}}{2}\right)}{I_{o}}-\left(\frac{V_{P}}{I_{o} \cdot R_{P}}\right)\right] \& n=0,1,2, \cdots, n \\
& p_{P V, f}(t)=-\left(\frac{-\Delta i_{P V}}{(1-D) T_{s}} \cdot t+I_{P V, a v r g}+\Delta i_{P V} \frac{(1+D)}{2(1-D)}\right)^{2} R_{s} \\
& +\left(\frac{-\Delta i_{P V}}{(1-D) T_{s}} \cdot t+\Delta i_{P V} \frac{(1+D)}{2(1-D)}\right) \cdot \alpha \cdot \ln \gamma \\
& \text { where, } \gamma=\left[\frac{I_{s}+I_{o}-\left(\frac{-\Delta i_{P V}}{(1-D) T_{s}} \cdot t+I_{P V, \text { avrg }}+\Delta i_{P V} \frac{(1+D)}{2(1-D)}\right)}{I_{o}}-\left(\frac{V_{P}}{I_{o} \cdot R_{P}}\right)\right]
\end{aligned}
$$

\& $n=0,1,2, \cdots, n$.

Equation (6) and Equation (7) exhibits the presence of current ripple $\left(\Delta i_{P V}\right)$ in the output power of PV module for both rise time and fall time. Thus the need for ripple 
cancelling technique is arrived to solve this dilemma of PV module.

\section{Proposed DMMO SEPIC Converter}

Schematic of the proposed DMMO (dual mode-multiple output) SEPIC converter is shown in Figure 4 and each part of the system is discussed in next subsections.

\subsection{Passive Ripple Cancelling Circuit (PRCC)}

PRCC are integrated into the input side of a conventional converter to eliminate the input current ripple. PRCC consists of a high frequency transformer modelling as an ideal transformer with turns ratio $N$ and a magnetizing inductor $L m$, a ripple mirror inductor $L_{r 1}$ as well as two blocking capacitors $C_{r 1}, C_{r 2}$ that are connected to the primary and the secondary winding of the transformer respectively.

In addition, each terminal of the proposed PRCC is connected to one of the main inductor $L_{1}$ terminals of the converter where the current ripple is generated. Due to the blocking capacitors of $C_{r 1}$ and $C_{r 2}$ as well as the reversal polarity of the transformer, only the high frequency ac voltage/current of inductor $L_{1}$ are reflected to $L_{r 1}$ automatically.

Wave shapes of Figure 5 demonstrate the working fundamental of PRCC. It can be observed that when the switch $S$ is turned on, $i_{L 1}$ exhibits a positive slope while $i_{L r 1}$ exhibits a negative slope. When the switch $S$ is turned off, $i_{L 1}$ exhibits a negative slope while $i_{L r 1}$ exhibits a positive slope. Thus mirror inductor attenuates input current ripple [13].

Equation of Input current ripple cancelling ratio is: $\delta=1-\left(\Delta i_{s} / \Delta i_{L 1}\right)$.

\subsection{Operating Principle of Proposed System}

Figure 6 illustrates three operating states of the proposed system.

- In state 1 , the PV array supplies power to load and possibly also to the battery, corresponding to the daytime operation of the PV system.

- In state 2, converter and loads are disconnected and the system enters into the stand-alone approach. The PV array charges battery without energy transferred to the load.

- In state 3, the battery supplies power to the load through the converter, indicating the nighttime operation of the stand-alone system.

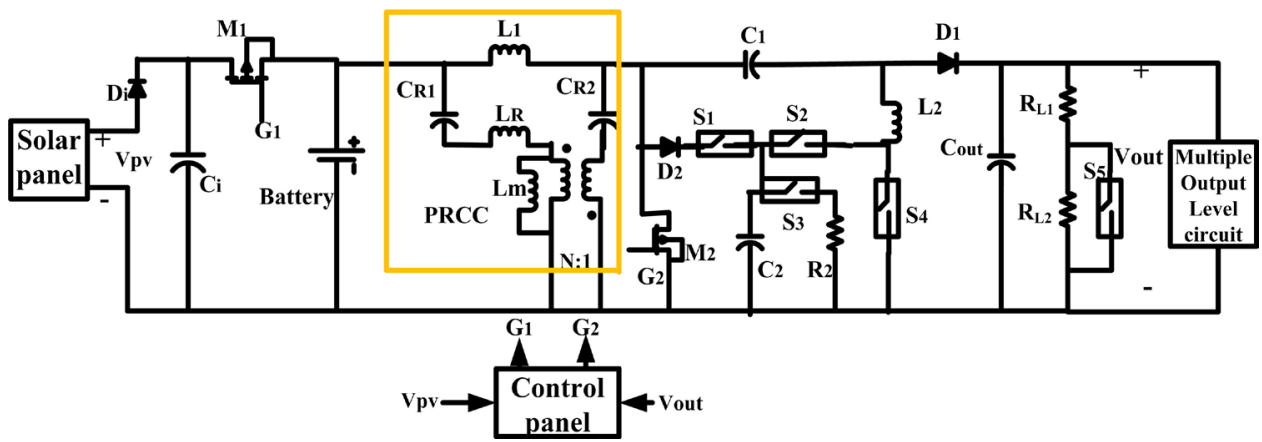

Figure 4. Circuit configuration of DMMO SEPIC converter integrated with passive ripple cancelling circuit (PRCC). 


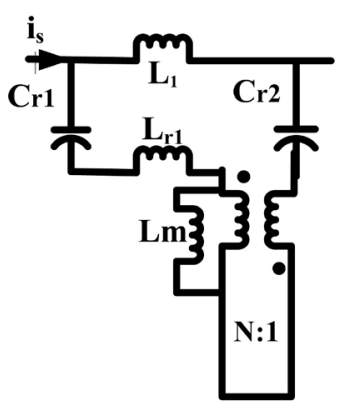

(a)

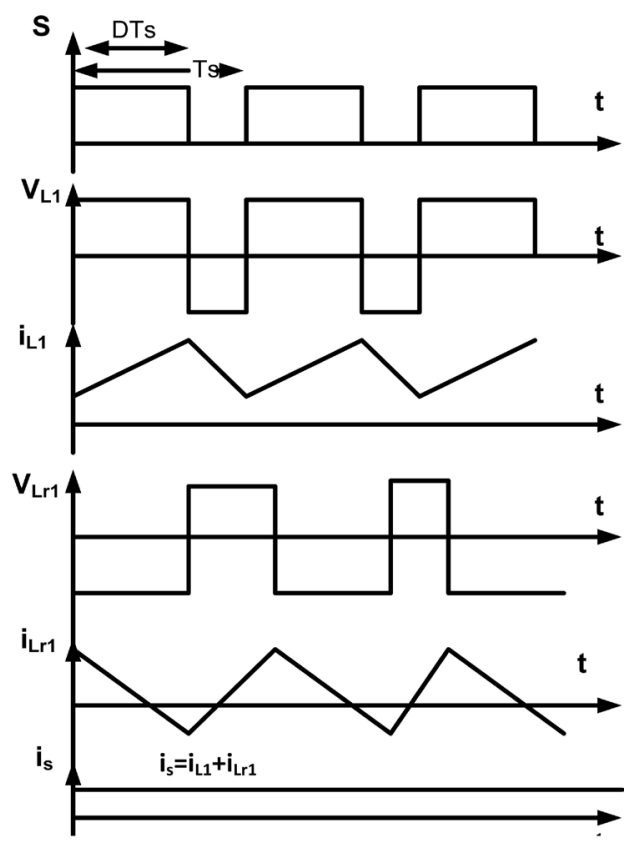

(b)

Figure 5. (a) Schematic diagram of PRCC, (b) Inductor voltage and current wave shapes for PRCC integrated converter.

State 1

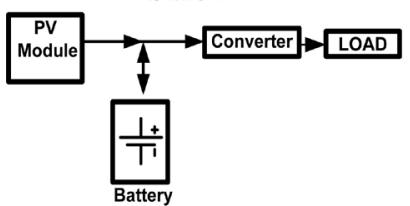

State 2

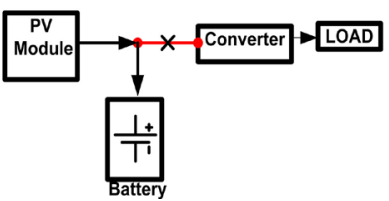

State 3

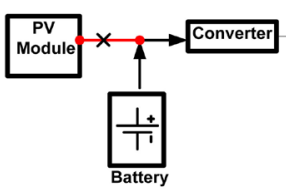

Figure 6. Three operation states of proposed converter.

\subsection{Operating Modes of the Converter}

\section{Mode I (Figure 7):}

Switch $S_{1}, S_{2}$ are turned on and $S_{3}, S_{4}$ and $S_{5}$ are turned off. Converter acts as the modified version of SEPIC [27] [28] providing high output voltage.

In this state, capacitor is being involved in the operation of the converter through $S_{1}$ and $\mathrm{S}_{2}$ switches. Effect of resistance $\mathrm{R}_{2}$ is isolated from the circuit by turning off switch $\mathrm{S}_{3}$.

- State I: Switch $M_{2}$ is turned-on and the diode $D_{1}$ is blocked and the inductors $L_{1}$ and $L_{2}$ store energy. The input voltage is applied to the input inductor $L_{1}$ through switch $M_{2}$. $C_{2}, L_{2}$ and $C_{1}$ complete a circuit without changing the direction of inductor current. Load is connected directly with output capacitor $C_{o}$.

- State II: Switch $\mathrm{M}_{2}$ is turned-off and the energy stored in the input inductor $L_{1}$ is transferred to the output through the capacitor $C_{1}$ and output diode $D_{1}$, and also to the capacitor $C_{2}$ through the diode $D_{2}$. Therefore, the switch voltage is equal to the capacitor $C_{2}$ voltage. The energy stored in the inductor $L_{2}$ is transferred to the output through the diode $D_{1}$. 


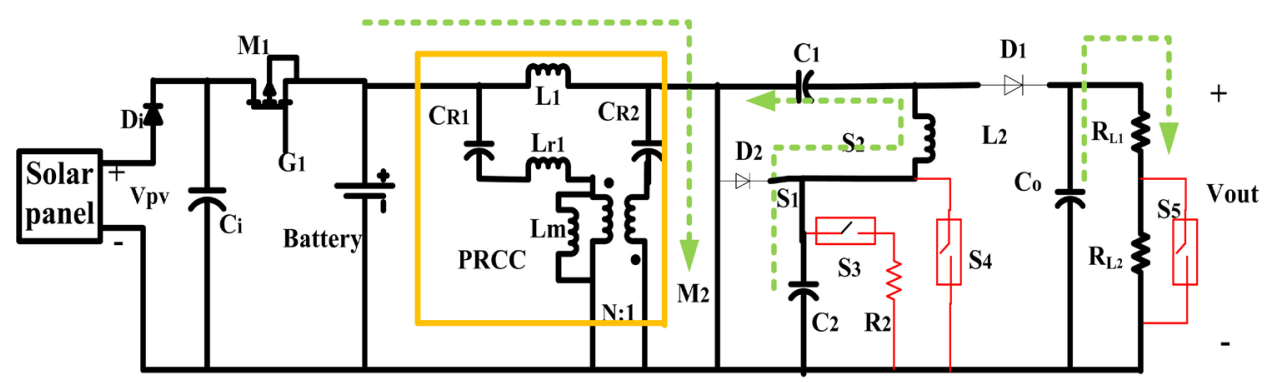

(a)

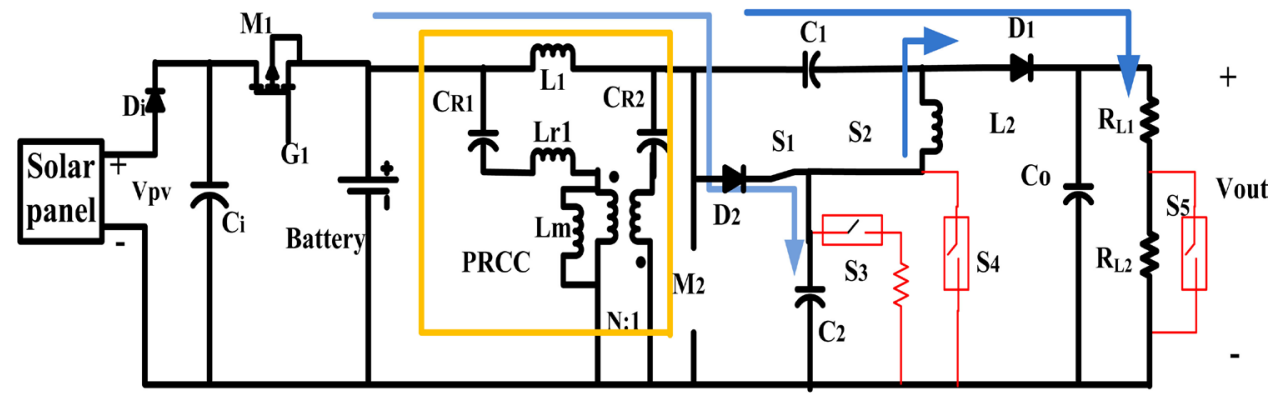

(b)

Figure 7. Operating states of the proposed converter in "Mode I" (a) state I (b) state II.

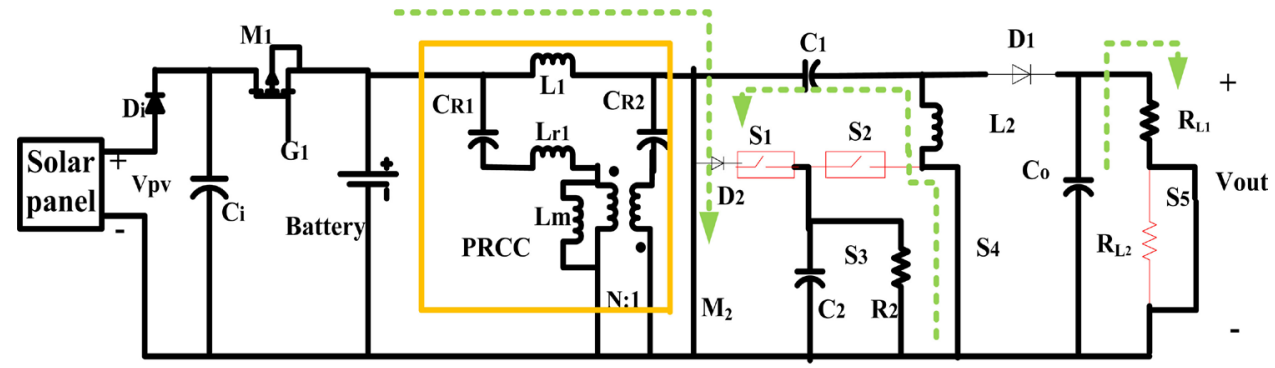

(a)

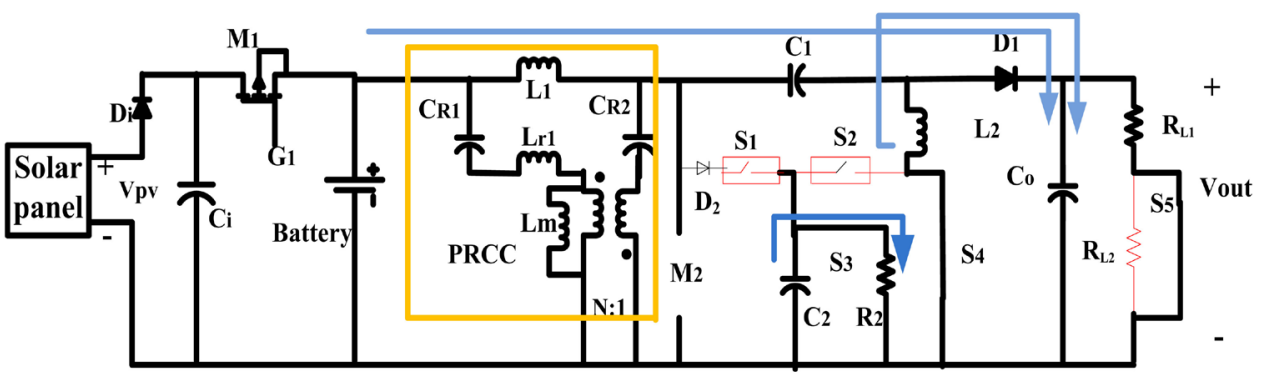

(b)

Figure 8. Operating states of the proposed converter in "Mode II" (a) state I (b) state II.

\section{Mode II (Figure 8):}

Switch $S_{1}, S_{2}$ are turned off and $S_{3}, S_{4}$ and $S_{5}$ are turned on. Converter acts as the conventional SEPIC [29] [30] converter. This state provides comparatively less step up ratio than mode I.

In this state of operation, diode $D_{2}$ is always reverse-biased and capacitor $\mathrm{C}_{2}$ is being 
isolated by switch $S_{1}$ and $S_{2}$, as well as it will complete a circuit with $R_{2}$ through switch $S_{3}$. Load resistance will be reduced by removing $R_{L 2}$ with the help of switch $S_{5}$.

- State I: Switch $M_{2}$ is turned on, current $i_{L 1}$ increases and the current $i_{L 2}$ goes more negative. The capacitor $C_{1}$ supplies the energy to increase the magnitude of the current in $i_{L 2}$, diode $D_{1}$ and $D_{2}$ are reverse-biased. $C_{o}$ supplies energy to the load $R_{L 1}$.

- State II: Switch $M_{2}$ is turned off. Current $i_{C t}$ becomes the same as the current $i_{L 1}$. Inductors do not allow instantaneous changes in current. Power is delivered to the load from both $L_{2}$ and $L_{1}$. However $C_{1}$ is being charged by $L_{1}$ during this off cycle, and will in turn recharge $L_{2}$ during the on cycle.

\subsection{Multiple Outputs}

Proposed topology of multiple output levels are being described in next sub section. The motivation of this study is to design a dual mode- multiple output (DMMO) converter for increasing the conversion efficiency and voltage gain, reducing the control complexity, and saving the manufacturing cost.

\subsection{Operation of Multiple Output Circuit}

Gate pulses Go2, Go3 and Go4 are the respective switching pulses for switches Mo2, $M o 3$ and Mo4, shown in Figure 9, as well as they are provided fixed duty cycle of $80 \%$, $50 \%$ and $30 \%$ subsequently. In Figure 10, four operating states are illustrated.

State I $\left(T_{0}-T_{1}\right)$ : In this state, switches Mo2, Mo3 and Mo4 are turned ON for a span. Along with these diodes Do2, Do3 and Do4 are being turned OFF. Three levels are directly connected to the converter.

State II $\left(T_{1}-T_{2}\right)$ : In this state, switches Mo2, Mo3 are turned ON and diodes Do2, D03 are turned OFF. For this span, switch Mo4 is turned OFF. Because of the polarity of inductor Lo4, diode Do4 turns $\mathrm{ON}$ and the output loop is connected to the inductor Lo4 through the diode Do4.

State III $\left(T_{2}-T_{3}\right)$ : Only switch $M o 2$ is turned $\mathrm{ON}$ and the corresponding diode Do2 is turned OFF. From multiple levels only the first level is directly connected with the

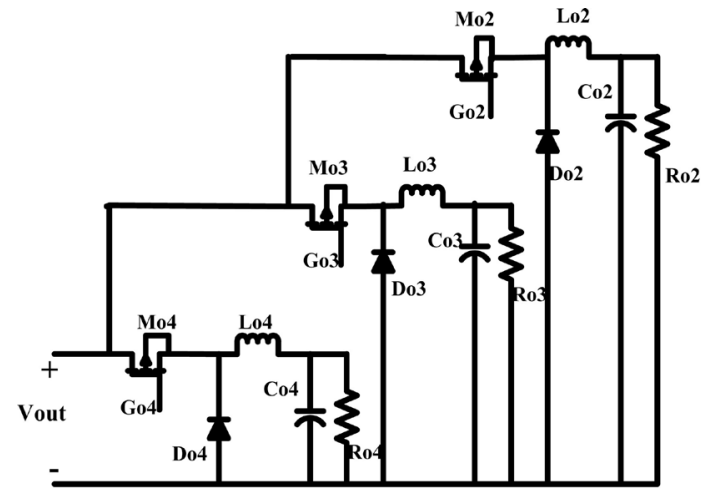

(a)

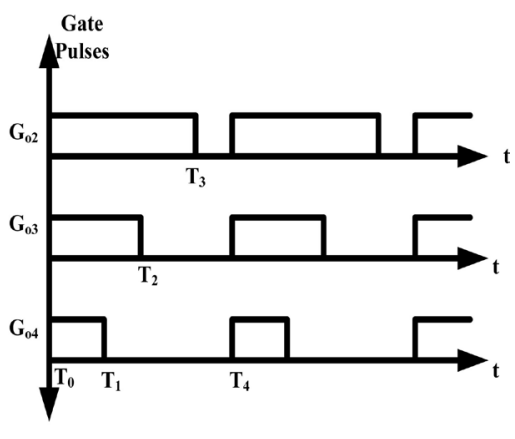

(b)

Figure 9. (a) Schematic of "Multiple Output Circuit" (b) Switching gate pulses of output level switches. 


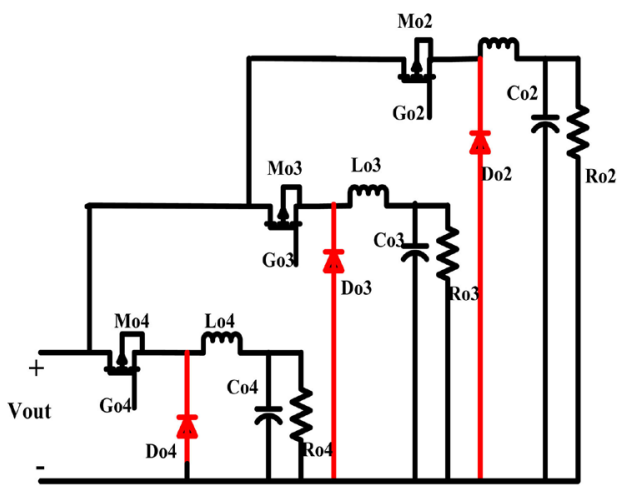

(a)

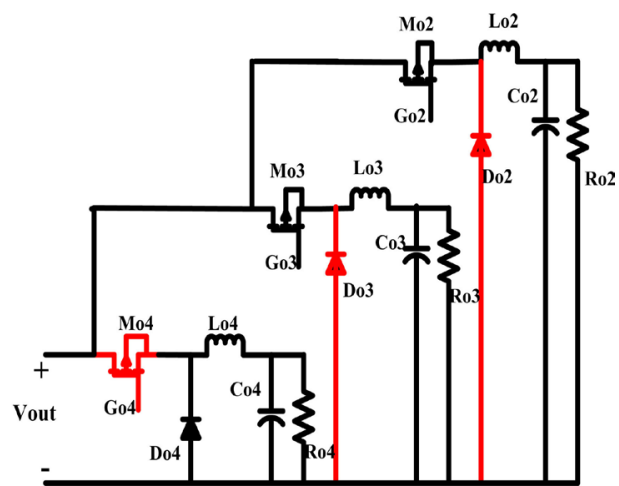

(b)

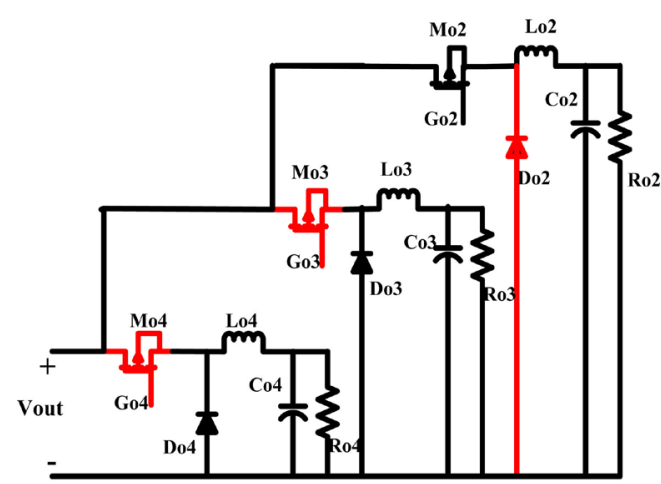

(c)

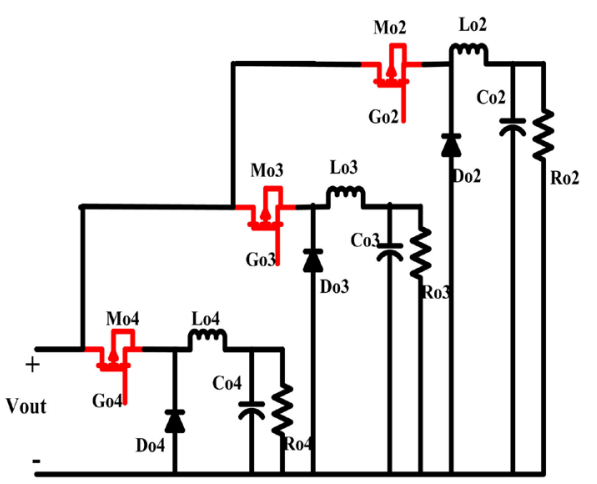

(d)

Figure 10. Operating states of the "Multiple Output Circuit" (a) state I (b) state II (c) state III (d) state IV.

converter circuit. Other two levels are connected to inductors Lo3 and Lo4 respectively, through corresponding diodes.

State IV $\left(T_{3}-T_{4}\right)$ : Output loops are completed individually through respective inductors and diodes as all the three switches are being turned OFF.

\subsection{Control Scheme}

The maximum power point tracking (MPPT) can be implemented by adjusting the duty cycle of switching device $M_{1}$ shown in Figure 4. In the MPPT loop, the PV voltage is regulated to follow an optimal operating point, which is initially assigned to $80 \%$ of the open-circuit voltage of the PV array. This point can be determined by the "constant voltage method". Moreover, the PV voltage regulation loop is used to improve the MPPT performance.

In Mode I, switch $S_{1}, S_{2}$ are turned on and $S_{3}, S_{4}$ and $S_{5}$ are turned off, when the converter act as modified SEPIC. On/off operation of these switches are complementary for mode II, when it acts as conventional SEPIC.

In the output voltage control loop shown, the duty cycle of switching device $M_{2}$ shown in Figure 4 is the control variable, which regulates the output voltage to follow the expected voltage. To serve this purpose PI controller is used. When the output power of the PV array is lower than the load power, the battery should supply the dif- 
ference. Here a single control scheme can regulate multiple output levels. The control block diagram of the proposed control scheme is illustrated in Figure 11.

\section{$>$ Constant Voltage Method:}

The solar array is temporarily isolated from the MPPT, and a $V_{O C}$ measurement is taken [31]. Next, the MPPT calculates the correct operating point using the equation mention below:

$$
\frac{V_{M P P}}{V_{o c}} \cong K<1
$$

And the pre-set value of $K$, and adjusts the array's voltage until the calculated $V_{M P P}$ is reached. This operation is repeated periodically to track the position of the MPP. Although this method is extremely simple, it is difficult to choose the optimal value of the constant $K$. Value of ranging from $73 \%$ to $80 \%$ [32] [33]. Figure 12 shows the actual $K$ values required for a given PV array over a temperature range of $0^{\circ} \mathrm{C}-60^{\circ} \mathrm{C}$ and irradiance levels from 200 to $1000 \mathrm{~W} / \mathrm{m}^{2}$. These curves were calculated using the I-V relationship for a PV cell.

\section{Proportional Integral Controller:}

The PI-Controller is a combination of a proportional and integral controller, which has two tuning parameters to adjust: proportional $(k p)$ and integral $(k i)$. PI controller is mainly used to eliminate the steady state error resulting from P controller [35] Figure 13 demonstrates the operating fundamentals of PI controller through block diagram.

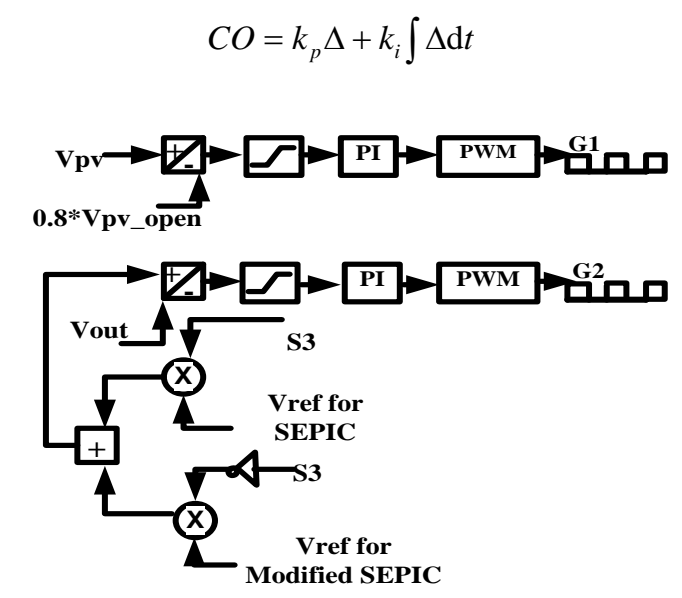

Figure 11. Schematic of control circuit.

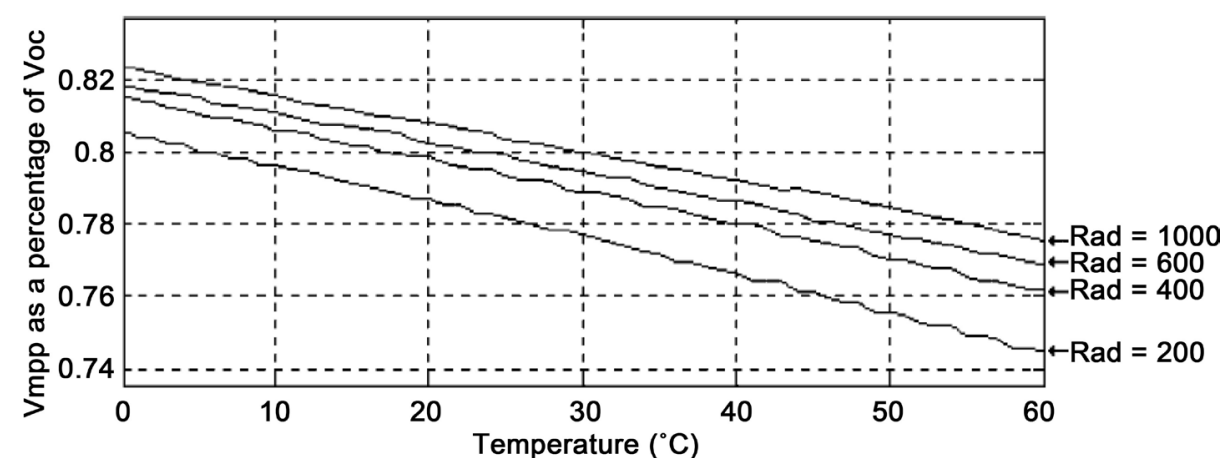

Figure 12. $V_{M P P}$ as a percentage of $V_{O C}$ as functions of temperature and irradiance [34]. 


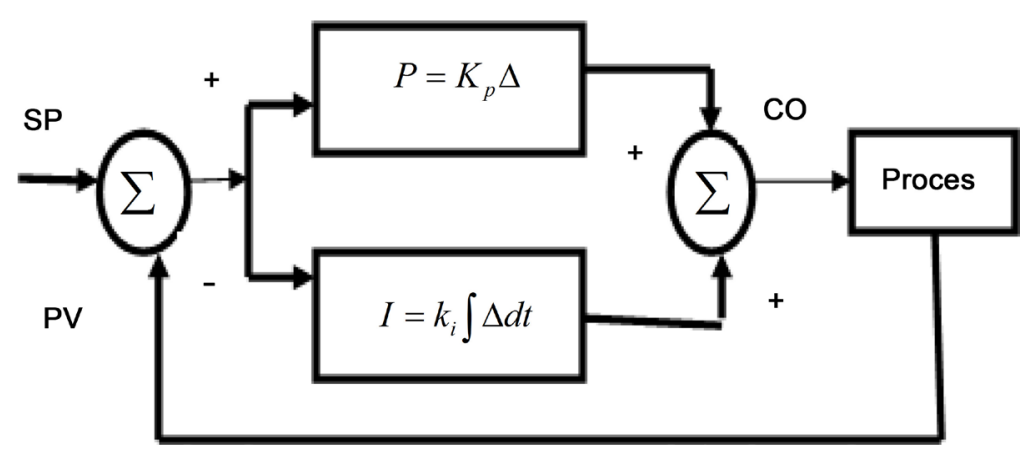

Figure 13. Block diagram of PI controller.

where, $\Delta=$ set point $(\mathrm{SP})$ - process variable(PV)

$C O=$ controller output signal

The integral term continually sums up error. Through constant summing, integral action accumulates influence based on how long and how far the measured PV has been from SP over time.

- Effect of $\left(k_{p}\right)$ :

- Increasing $k_{p}$ will reduce the steady state error.

- After certain limit increasing $k_{p}$ only causes overshoot.

- Increasing $k_{p}$ reduces the rise time [36].

* Effect of $\left(k_{i}\right)$.

- Integral control eliminates the steady state error.

- After certain limit, increasing $k_{i}$ will only increase overshoot.

- Increasing $k_{i}$ reduces the rise time a little.

\section{Simulation and Observation}

In order to verify the performance of the proposed system, simulation work is carried out in the MATLAB/SIMULINK environment. For simulating the system, PV panel specifications are set under $1000 \mathrm{~W} / \mathrm{m}^{2}$ irradiance and $30^{\circ} \mathrm{C}$ temperature condition.

Figure 14(a) shows voltage and current waveforms of the input side. As shown in Figure 14(a), the PV voltage is regulated to $12.8 \mathrm{~V}$, which represents the MPP (maximum power point) and PV current more closely approximates DC, with an average value of about 3.859 A. Consequently, output voltage is desired to be regulated on 100 $\mathrm{V}$ for mode-1. As seen from Figure 14(b), output voltage is $99.14 \mathrm{~V}$ and output current is $0.49 \mathrm{~A}$, as a result converter provides output power of 49.57 watt with 7.75 voltage step up ratio.

Figure 15(a) illustrates multiple output voltage levels for mode I at $80 \mathrm{~V}, 50 \mathrm{~V}$ and $30 \mathrm{~V}$. Along with these, Figure 15(b) presents corresponding currents waveforms. This mode provides high voltage step up ratio which is applicable for long distance high voltage systems. Figure 16(a) presents PV voltage and current waveforms indicating maximum power point achieved at $12.8 \mathrm{~V}$ providing 49.39 watt input power. As seen in Figure 16(b), output voltage is regulated at desired point of $50 \mathrm{~V}$ for mode II. Moreover this mode provides voltage step up ratio of 3.9. Converter output voltage and cur- 
rent wave shapes expose that, steady state arrive earlier in mode II than mode I. As well as Figure 17(a) displays 3 voltage levels of $40 \mathrm{~V}, 20 \mathrm{~V}$ and $15 \mathrm{~V}$ of mode II. Figure 17(b) shows multi level output current wave shapes subsequently.

Table 1 exhibits high efficient feature of the proposed converter as it provides 98.35\% and $97.76 \%$ efficiency subsequently for mode I and mode II. Therefore, Table 2 presents different electrical properties of multiple output levels.
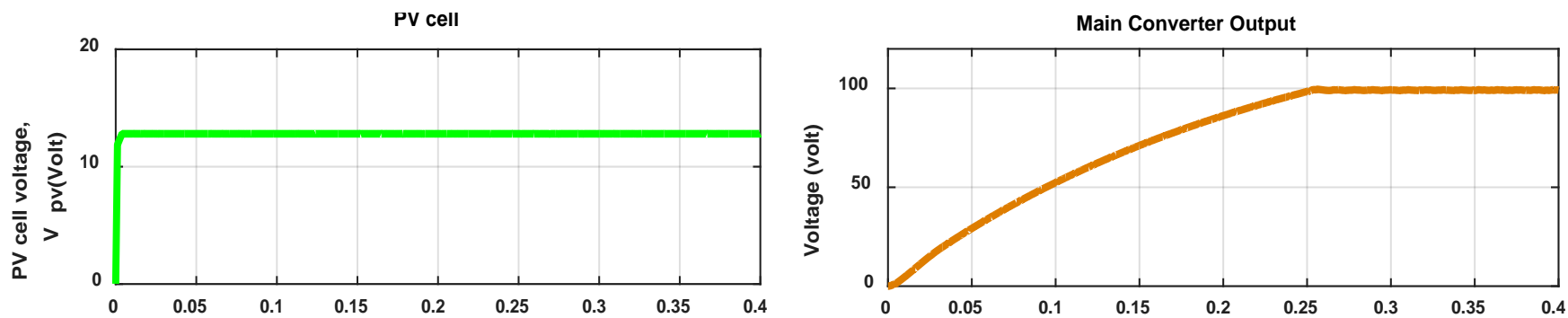

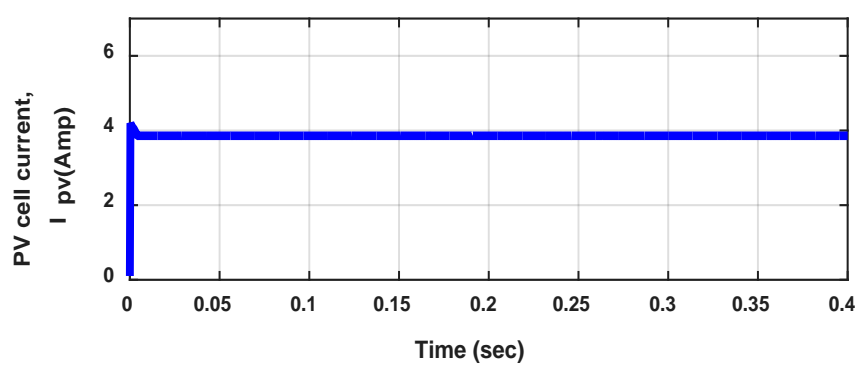

(a)

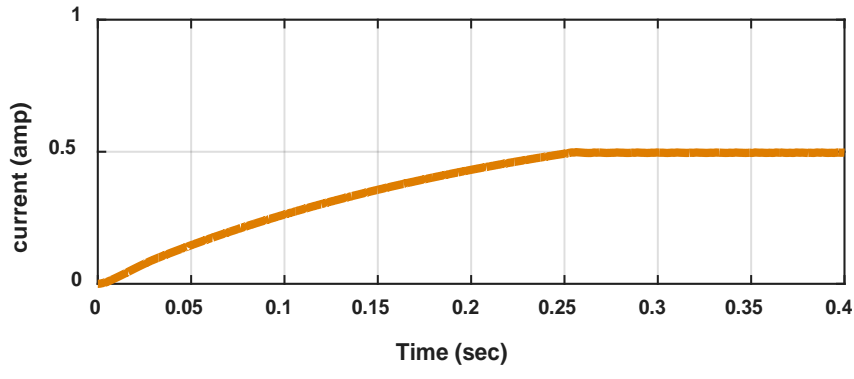

(b)

Figure 14. (a) Input voltage and current waveshapes of PV module (Mode I); (b) Waveshapes of multilevel current outputs (Mode I).
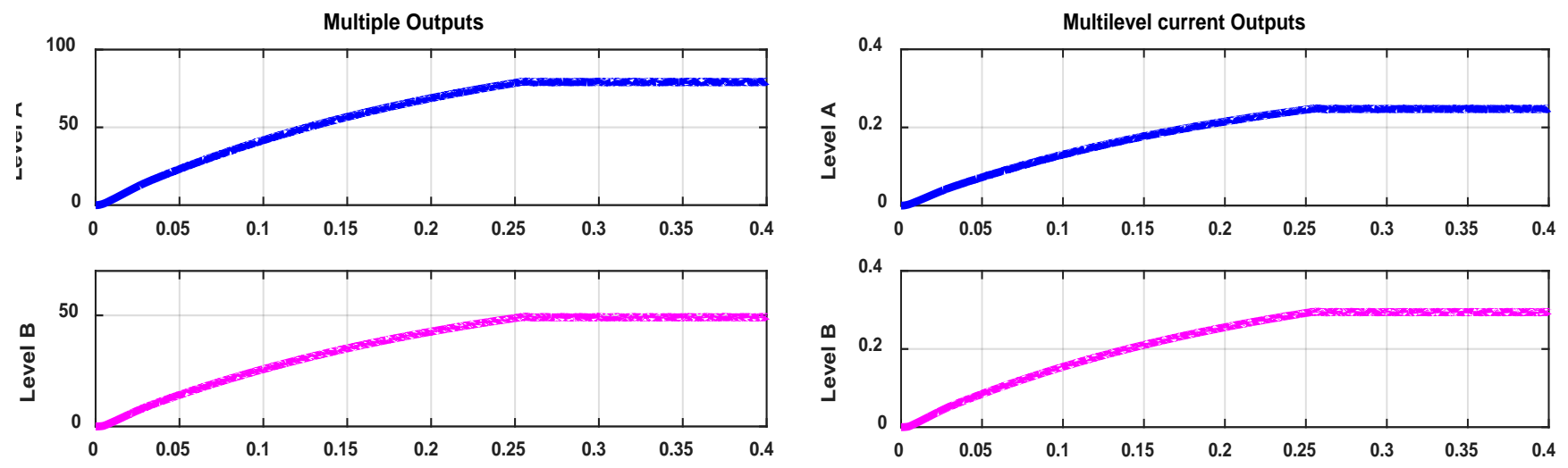

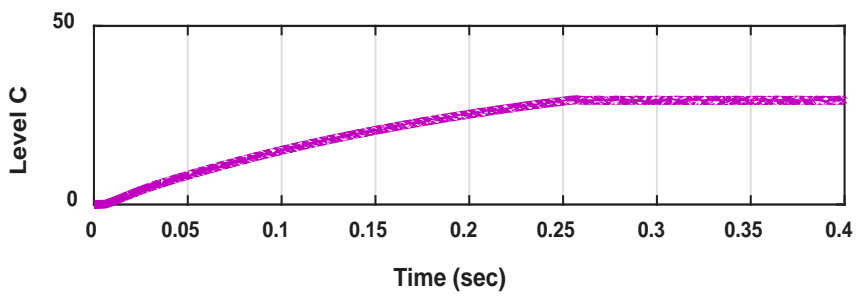

(a)

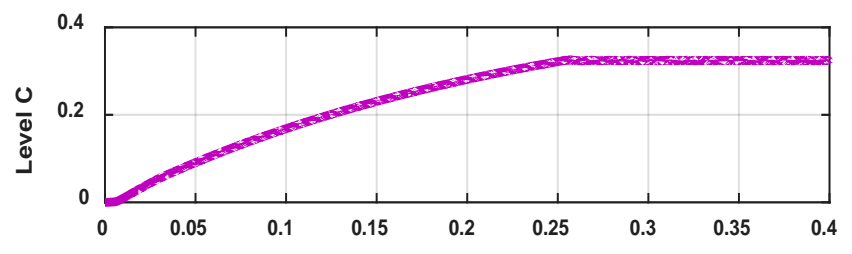

(b)

Figure 15. (a)Voltage waveshapes of multiple output levels (Mode I); (b) Current waveshapes of multiple output levels (Mode I). 

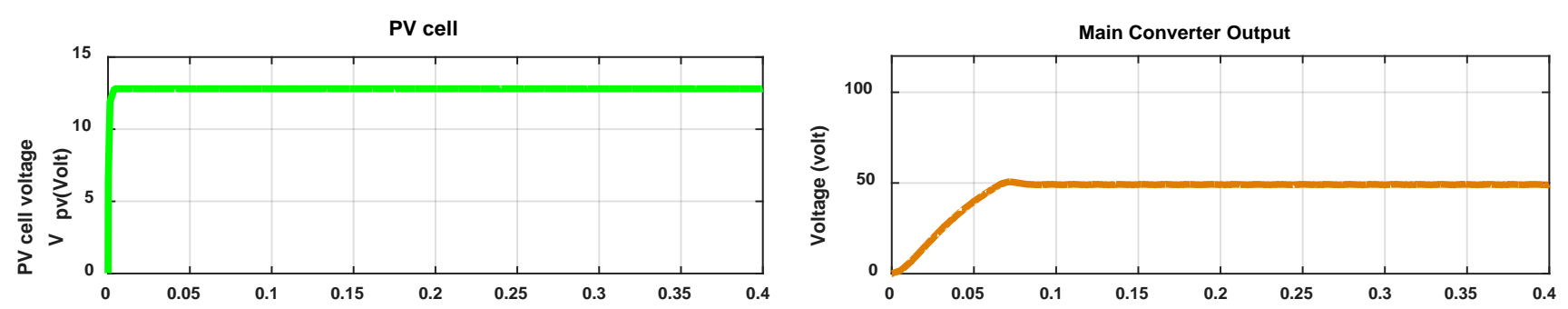

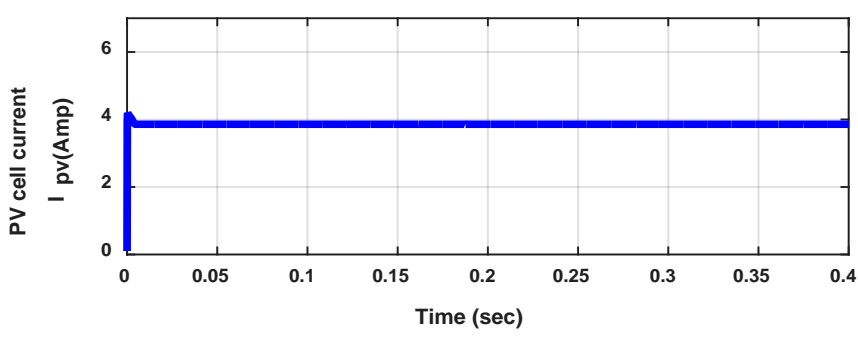

(a)

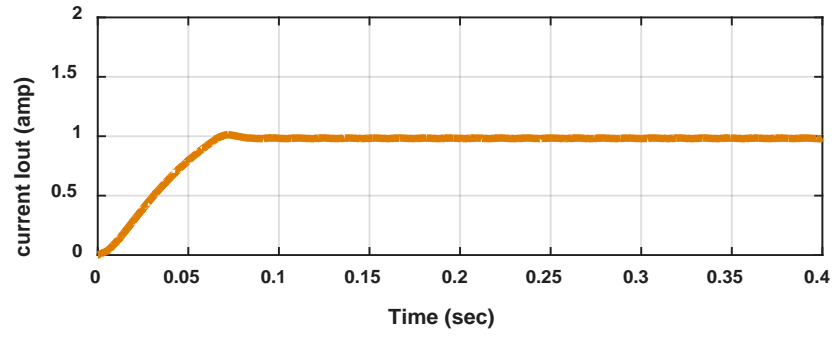

(b)

Figure 16. (a) Input voltage and current waveshapes of PV module (ModeII); (b) Output voltage and current waveshapes of the main converter (Mode II).
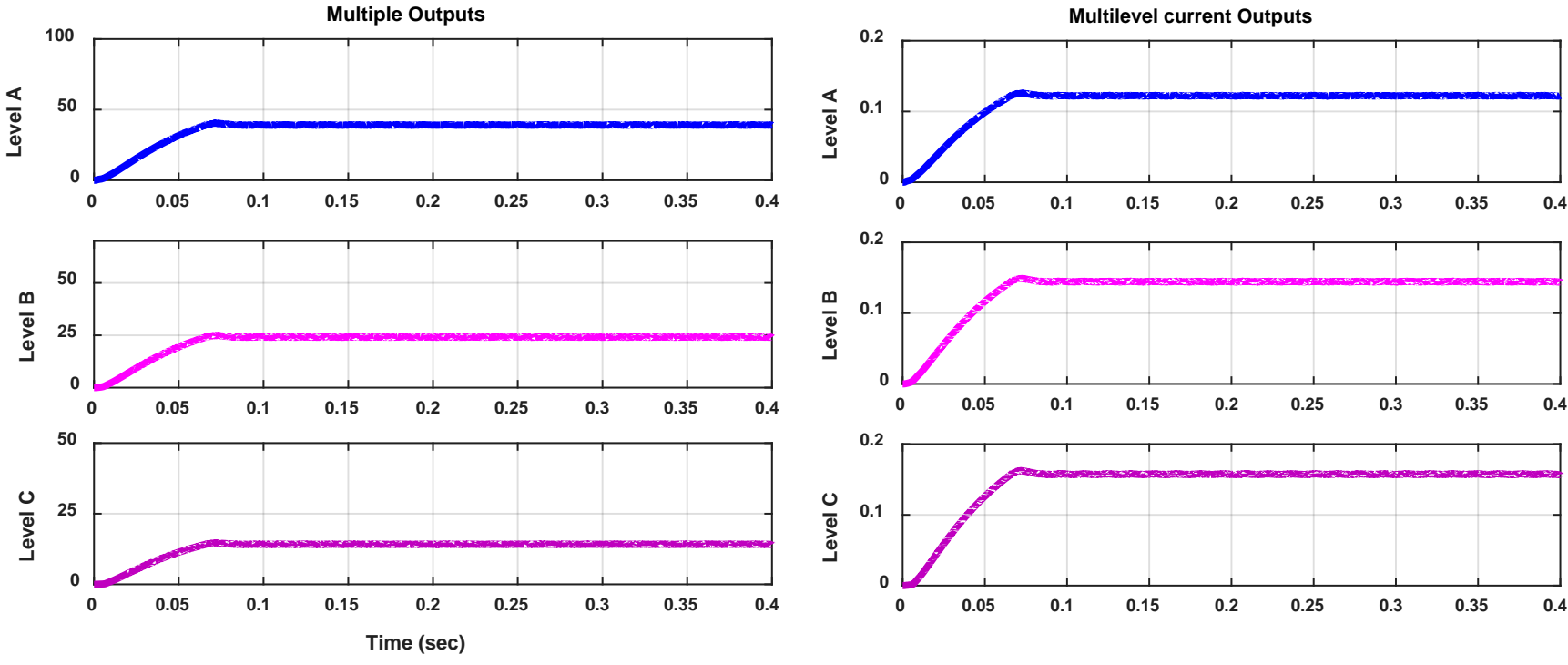

(a)

(b)

Figure 17. (a) Voltage waveshapes of multiple output levels (Mode II); (b) Waveshapes of multilevel current outputs (Mode II).

Table 1. Electrical parameters of input and output of proposed dual mode converter.

\begin{tabular}{|c|c|c|c|c|c|c|}
\hline Converter & \multicolumn{3}{|c|}{ Input } & \multicolumn{3}{|c|}{ Converter Output } \\
\hline $\begin{array}{c}\text { Mode I } \\
\text { [Modified SEPIC] }\end{array}$ & 12.8 & 3.859 & 49.39 & 99.14 & $\begin{array}{c}0.49 \\
\text { Efficiency: } 98.35 \%\end{array}$ & 49.57 \\
\hline $\begin{array}{l}\text { Mode II } \\
\text { [SEPIC] }\end{array}$ & 12.8 & 3.859 & 49.39 & 49.16 & $\begin{array}{c}0.9823 \\
\text { Efficiency: } 97.76 \%\end{array}$ & 48.29 \\
\hline
\end{tabular}


Table 2. Electrical properties of output levels.

\begin{tabular}{cccccccccc}
\hline & \multicolumn{9}{c}{ Output Levels } \\
\cline { 2 - 9 } Converter & \multicolumn{3}{c}{ Level A } & \multicolumn{3}{c}{ Level B } & \multicolumn{3}{c}{ Level C } \\
\cline { 2 - 9 } & Vo2 (Volt) & Io2 (Amp) & Po2 (watt) & Vo3 (Volt) & Io3 (Amp) & Po3 (watt) & Vo4 (Volt) & Io4 (Amp) & Po4 (watt) \\
\hline Mode I [Modified SEPIC] & 79.32 & 0.2469 & 19.58 & 49.26 & 0.2943 & 14.5 & 29.25 & 0.3248 & 9.5 \\
Mode II [SEPIC] & 39.19 & 0.1224 & 4.79 & 24.08 & 0.1447 & 3.48 & 14.18 & 0.1572 & 2.22 \\
\hline
\end{tabular}

\section{Conclusion}

This paper has presented an efficient Dual Mode-Multiple Output (DMMO) converter for stand-alone PV system, based on SEPIC topology. The converter can provide a high step-up capability for power conversion systems. The main benefits of this topology include: continuous supply to the load; mode can vary according to distance and requirements; a high conversion ratio; allowing high switching frequency; it can be implemented in modular form and more levels can be added without changing the main converter; reducing input current ripple with a passive circuit; a single control scheme reduces circuit complicacy and control scheme is consolidated with input and output control strategy. Two operating modes with different states are analyzed and simulation is performed to show the effective operation of the proposed topology for PV applications.

\section{References}

[1] Li, W., Xiang, X., Hu, Y. and He, X. (2014) High Step-Up Interleaved Converter with BuiltIn Transformer Voltage Multiplier Cells for Sustainable Energy Applications. IEEE Transactions on Power Electronics, 29, 2829-2836. http://dx.doi.org/10.1109/TPEL.2013.2273977

[2] Gu, Y., Li, W., Zhao, Y., Yang, B., Li, C. and He, X. (2013) Transformerless Inverter with Virtual DC Bus Concept for Cost-Effective Grid-Connected PV Power Systems. IEEE Transactions on Power Electronics, 28, 793-805. http://dx.doi.org/10.1109/TPEL.2012.2203612

[3] Spiazzi, G., Mattavelli, P. and Costabeber, A. (2011) High Step-Up Ratio Flyback Converter with Active Clamp and Voltage Multiplier. IEEE Transactions on Power Electronics, 26, 3205-3214. http://dx.doi.org/10.1109/TPEL.2011.2134871

[4] Thounthong, P. (2011) Model Based-Energy Control of a Solar Power Plant with a Supercapacitor for Grid-Independent Applications. IEEE Transactions on Energy Conversion, 26, 1210-1218. http://dx.doi.org/10.1109/TEC.2011.2168400

[5] Elmitwally, A. and Rashed, M. (2011) Flexible Operation Strategy for an Isolated PV-Diesel Microgrid without Energy Storage. IEEE Transactions on Energy Conversion, 26, 235-244. http://dx.doi.org/10.1109/TEC.2010.2082090

[6] Valderrama-Blavi, H., Bosque, J.M., Guinjoan, F., Marroyo, L. and Martinez-Salamero, L. (2013) Power Adaptor Device for Domestic DC Microgrids Based on Commercial MPPT Inverters. IEEE Transactions on Industrial Electronics, 60, 1191-1203. http://dx.doi.org/10.1109/TIE.2012.2198038

[7] Wu, H., Sun, K., Chen, R., Hu, H. and Xing, Y. (2012) Full-Bridge Three-Port Converters with Wide Input Voltage Range for Renewable Power Systems. IEEE Transactions on 
Power Electronics, 27, 3965-3974. http://dx.doi.org/10.1109/TPEL.2012.2188105

[8] Li, W., Fan, L., Zhao, Y., He, X., Xu, D. and Wu, B. (2012) High Step-Up and High Efficiency Fuel Cell Power Generation System with Active Clamp Flyback forward Converter. IEEE Transactions on Industrial Electronics, 59, 599-610. http://dx.doi.org/10.1109/TIE.2011.2130499

[9] Zhao, Y., Xiang, X., Li, W., He, X. and Xia, C. (2013) Advanced Symmetrical Voltage Quadrupler Rectifiers for High Step-Up and High Output-Voltage Converters. IEEE Transactions on Power Electronics, 28, 1622-1631. http://dx.doi.org/10.1109/TPEL.2012.2211108

[10] Li, W. and He, X. (2011) Review of Non-Isolated High Step-Up DC/DC Converters in Photovoltaic Grid-Connected Applications. IEEE Transactions on Industrial Electronics, 58, 1239-1250. http://dx.doi.org/10.1109/TIE.2010.2049715

[11] Sullivan, C.R., Awerbuch, J.J. and Latham, A.M. (2013) Decrease in Photovoltaic Power Output from Ripple: Simple General Calculation and the Effect of Partial Shading. IEEE Transactions on Power Electronics, 28, 740-747. http://dx.doi.org/10.1109/TPEL.2012.2205162

[12] Benavides, N.D. and Chapman, P.L. (2008) Modeling the Effect of Voltage Ripple on the Power Output of Photovoltaic Modules. IEEE Transactions on Industrial Electronics, 55, 2638-2643. http://dx.doi.org/10.1109/TIE.2008.921442

[13] Pan, C.T., Cheng, M.C., Lai, C.M. and Chen, P.Y. (2015) Current-Ripple-Free Module Integrated Converter with More Precise Maximum Power Tracking Control for PV Energy Harvesting. IEEE Transactions on Industry Applications, 51, 271-278. http://dx.doi.org/10.1109/TIA.2014.2326076

[14] Rashid, M.H. (2013) Power Electronics: Devices, Circuits, and Applications. 4th Edition, Pearson Education, Harlow.

[15] Nahavandi, A., Hagh, M.T., Sharifian, M.B.B. and Danyali, S. (2015) A Nonisolated Multiinput Multioutput DC-DC Boost Converter for Electric Vehicle Applications. IEEE Transactions on Power Electronics, 30, 1818-1835. http://dx.doi.org/10.1109/TPEL.2014.2325830

[16] Zheng, Y., Ho, M., Guo, J., Mak, K.-L. and Leung, K. N. (2016) A Single-Inductor MultipleOutput Auto-Buck-Boost DC-DC Converter with Autophase Allocation. IEEE Transactions on Power Electronics, 31, 2296-2313. http://dx.doi.org/10.1109/TPEL.2015.2432040

[17] Liang, N.J., Dijkhuizen, F. and Demetriades, G.D. (2015) Modular Multilevel Converters for HVDC Applications: Review on Converter Cells and Functionalities. IEEE Transactions on Power Electronics, 30, 18-36. http://dx.doi.org/10.1109/TPEL.2014.2327641

[18] Rodriguez-Diaz, E., Savaghebi, M., Vasquez, J.C. and Guerrero, J.M. (2015) An Overview of Low Voltage DC Distribution Systems for Residential Applications. 5th International Conference on Consumer Electronics, Berlin, 6-9 September 2015, 318-322. http://dx.doi.org/10.1109/icce-berlin.2015.7391268

[19] Liu, S. and Dougal, R.A. (2002) Dynamic Multiphysics Model for Solar Array. IEEE Transactions on Energy Conversion, 17, 285-294. http://dx.doi.org/10.1109/TEC.2002.1009482

[20] Ahmad, T., Sobhan, S. and Nayan, M.F. (2016) Comparative Analysis between Single Diode and Double Diode Model of PV Cell: Concentrate Different Parameters Effect on Its Efficiency. Journal of Power and Energy Engineering, 4, 31-46. http://dx.doi.org/10.4236/jpee.2016.43004

[21] Gow, J.A. and Manning, C.D. (1999) Development of a Photovoltaic Array Model for Use in Power-Electronics Simulation Studies. IEE Proceedings B Electric Power Applications, 
146, 193-200. http://dx.doi.org/10.1049/ip-epa:19990116

[22] Gow, J.A. and Manning, C.D. (1996) Development of a Model for Photovoltaic Arrays Suitable for Use in Simulation Studies of Solar Energy Conversion Systems. 6th International Conference on Power Electronics and Variable Speed Drives, Nottingham, 23-25 September 1996, 69-74. http://dx.doi.org/10.1049/cp:19960890

[23] Kurobe, K. and Matsunami, H. (2005) New Two-Diode Model for Detailed Analysis of Multicrystalline Silicon Solar Cells. Japanese Journal of Applied Physics, 44, 8314-8321. http://dx.doi.org/10.1143/JJAP.44.8314

[24] Nishioka, K., Sakitani, N., Kurobe, K., Yamamoto, Y., Ishikawa, Y., Uraoka, Y. and Fuyuki, T. (2003) Analysis of the Temperature Characteristics in Polycrystalline Si Solar Cells Using Modified Equivalent Circuit Model. Japanese Journal of Applied Physics, 42, 7175-7179. http://dx.doi.org/10.1143/JJAP.42.7175

[25] Pan, C.T., Chen, J.Y., Chu, C.P. and Huang, Y.S. (1999) A Fast Maximum Power Point Tracker for Photovoltaic Power Systems. 25th Annual Conference of the IEEE Industrial Electronics Society, San Jose, 29 November-3 December 1999, 390-393.

[26] Villalva, M.G., Gazoli, J.R. and Filho, E.R. (2009) Comprehensive Approach to Modeling and Simulation of Photovoltaic Arrays. IEEE Transactions on Power Electronics, 24, 1198 1208. http://dx.doi.org/10.1109/TPEL.2009.2013862

[27] De Melo, P.F., Gules, R., Romaneli, E.F.R. and Annunziato, R.C. (2010) A Modified SEPIC Converter for High-Power-Factor Rectifier and Universal Input Voltage Applications. IEEE Transactions on Power Electronics, 25, 310-321. http://dx.doi.org/10.1109/TPEL.2009.2027323

[28] Kalavathy, G. (2016) Comparison of Modified SEPIC and Traditional SEPIC Converter for Photovoltaic Energy Generation System Using Improved Hill Climbing Algorithm. International Journal of Engineering Science and Computing, 5261-5266.

[29] Mohan, N., Undeland, T.M. and Robbins, W.P. (2002) Power Electronics: Converters, Applications, and Design. 3rd Edition, John Wiley and Sons, New York.

[30] Do, H.-L. (2012) Soft-Switching SEPIC Converter with Ripple-Free Input Current. IEEE Transactions on Power Electronics, 27, 2879-2887. http://dx.doi.org/10.1109/TPEL.2011.2175408

[31] Eltawil, M.A. and Zhao, Z. (2013) MPPT Techniques for Photovoltaic Applications. Renewable and Sustainable Energy Reviews, 25, 793-813. http://dx.doi.org/10.1016/j.rser.2013.05.022

[32] Pandey, A., Dasgupta, N. and Mukerjee, A.K. (2007) A Simple Single-Sensor MPPT Solution. IEEE Transactions on Power Electronics, 22, 698-700. http://dx.doi.org/10.1109/TPEL.2007.892346

[33] Li, W., Zheng, Y., Li, W., Zhao, Y. and He, X. (2010) A Smart and Simple PV Charger for Portable Applications. 25 th Annual IEEE Applied Power Electronics Conference and Exposition, Palm Springs, 21-25 February 2010, 2080-2084. http://dx.doi.org/10.1109/apec.2010.5433522

[34] Hohm, D. and Ropp, M.E. (2002) Comparative Study of Maximum Power Point Tracking Algorithms. Progress in Photovoltaics. Research and Applications, 11, 47-62. http://dx.doi.org/10.1002/pip.459

[35] Selvaraj, J. and Rahim, N.A. (2009) Multilevel Inverter for Grid-Connected PV System Employing Digital PI Controller. IEEE Transactions on Industrial Electronics, 56, 149-158. http://dx.doi.org/10.1109/TIE.2008.928116 
[36] Awasthi, S.K., Sehgal, S. and Kumar, H. (2016) Comparative Analysis of Different Modes of a PID Controller Using a Hydraulic Level Control Trainer. International Conference on Futuristic Trends in Engineering, Science, Humanities, and Technology, Gwalior, 23-24 January 2016, 50-54.

Submit or recommend next manuscript to SCIRP and we will provide best service for you:

Accepting pre-submission inquiries through Email, Facebook, LinkedIn, Twitter, etc. A wide selection of journals (inclusive of 9 subjects, more than 200 journals)

Providing 24-hour high-quality service

User-friendly online submission system

Fair and swift peer-review system

Efficient typesetting and proofreading procedure

Display of the result of downloads and visits, as well as the number of cited articles

Maximum dissemination of your research work

Submit your manuscript at: http://papersubmission.scirp.org/

Or contact jpee@scirp.org 